\title{
Recurrent and Bilateral Peritonsillar Abscess: A Rare Cause of Upper Airway Obstruction
}

\author{
Tekrarlayan ve Bilateral Peritonsiller Apse: Üst Hava Yolu Obstrüksiyonunun Nadir Bir \\ Nedeni
}

\author{
(1) Leman Akcan Yıldız'1, (1) Dilara Ünal2 ${ }^{2}$ (1) Özlem Tekşam ${ }^{1}$ \\ ${ }_{1}^{1}$ Hacettepe University Ihsan Doğramacı Children Hospital, Pediatric Emergency Department, Ankara, Turkey \\ ${ }^{2}$ Hacettepe University ihsan Doğramacı Children Hospital, General Pediatrics Department, Ankara, Turkey
}

\section{Abstract}

Peritonsillar abscess is a rare but serious complication of acute tonsillitis. Bilateral peritonsillar abscess must be diagnosed and treated promptly because it can cause upper airway obstruction. In this case report, we report a patient with bilateral peritonsillar abscess, who presented with a sore throat, fever and difficulty swallowing and underwent unilateral peritonsillar abscess drainage one year ago.

Keywords: Airway obstruction, paediatric emergency medicine, peritonsillar abscess

\section{Öz}

Peritonsiller apse, akut tonsillitin nadir ancak ciddi bir komplikasyonudur. Bilateral peritonsiller apse, üst hava yolu obstrüksiyonuna yol açabileceğinden hızlı tanınmalı ve derhal tedavi edilmelidir. Bu yazıda boğaz ağrısı, ateş ve yutma güçlüğü yakınmaları ile başvuran; bir yıl önce tek taraflı peritonsiller apse drenajı öyküsü bulunan bir hastada üst hava yolu obstrüksiyonuna neden olan bilateral peritonsiller apse olgusu takdim edilmiştir.

Anahtar Kelimeler: Hava yolu obstrüksiyonu, çocuk acil, peritonsiller apse

Unless the peritonsillar abscess is too small to drain, its treatment consists of antibiotics and drainage. Empirical antibiotics against streptococci and staphylococci should be preferred. If the patient has recovered and can tolerate the oral intake of food and antibiotics, they can be discharged from the hospital and amoxicillin and clavulanate or clindamycin is administered. If the patient needs hospitalisation, sulbactam/ ampicillin or clindamycin is the appropriate treatment. ${ }^{1}$ Without treatment, the peritonsillar abscess may invade the base of the skull or mediastinum, causing life-treating complications. The possible complications of untreated peritonsillar abscess are the invasion of parapharyngeal or retropharyngeal space, epiglottitis and laryngeal oedema that can threaten the airway, thrombophlebitis of the jugular vein,

Address for Correspondence/Yazışma Adresi: Leman Akcan Yıldız, Hacettepe University İhsan Doğramacı Children Hospital, Pediatric Emergency Department, Ankara, Turkey

E-mail: lemanakcanyildiz@gmail.com ORCID ID: orcid.org/0000-0003-2584-6144

Received/Geliş Tarihi: 18.05.2020 Accepted/Kabul Tarihi: 22.07.2020 
lung abscess and meningitis. ${ }^{1}$ We report here a patient who presented to the emergency department with upper airway obstruction and was eventually diagnosed with bilateral peritonsillar abscess and treated successfully.

\section{Case Report}

A seven-year-old female presented to the emergency department with a four-day history of fever, sore throat, and difficult and painful swallowing. She was unable to open her mouth fully, was drooling and had a muffled voice and sleep impairment. She had a history of unilateral peritonsillar abscess treated with incision, drainage and antibiotics one year ago.

On physical examination, she was pale and sick and had a fever $\left(38.6^{\circ} \mathrm{C}\right)$, tachycardia (140 beats/min), and tachypnoea. Oral examination revealed an abundance of secretions and bilaterally enlarged and inflamed tonsils. The uvula was on the midline, and the soft palate was oedematous. Neck examination revealed a bilaterally tender submandibular lymphadenopathy. Systemic examination was otherwise normal.

Her laboratory results were as follows: white blood cell count

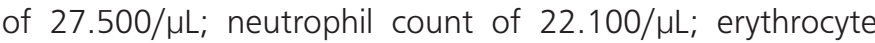
sedimentation rate of $92 \mathrm{~mm} / \mathrm{hr}$ (normal range: $<20 \mathrm{~mm} / \mathrm{hr}$ ); C-reactive protein level of $22.7 \mathrm{mg} / \mathrm{dL}$ (normal range: $0-0.8$ ) Contrast-enhanced computed tomography revealed bilateral peritonsillar abscess (Figure 1).

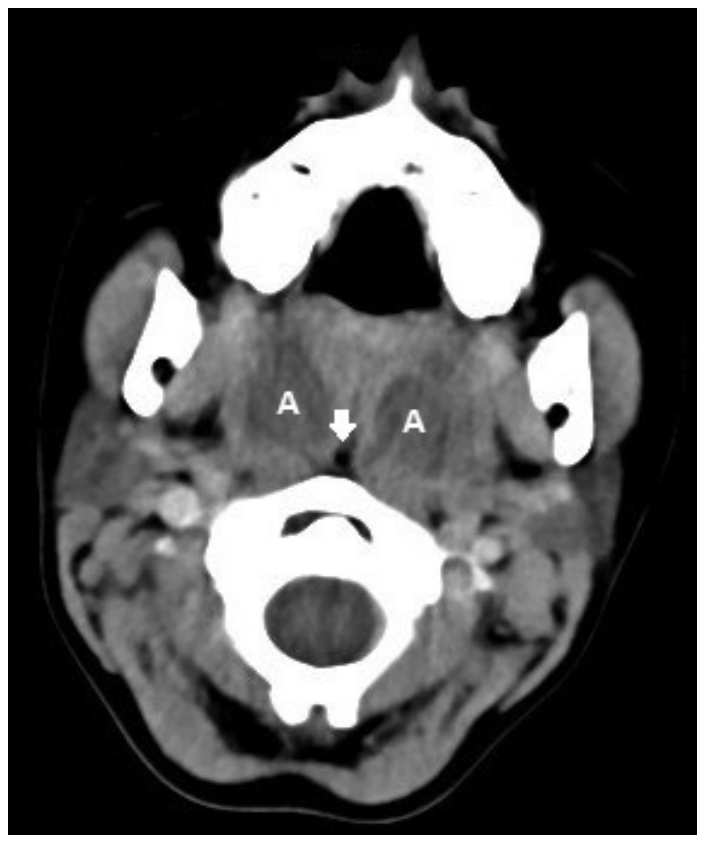

Figure 1. Contrast-enhanced axial computerised tomography showing a bilateral peritonsillar abscess (A, $27 \times 18 \mathrm{~mm}$ on the right side and $27 \times 12 \mathrm{~mm}$ on the left) and obstructed, narrow oropharyngeal air column
A bilateral needle aspiration was performed at the emergency department, and $7 \mathrm{~mL}$ of purulent material was drained. After admission to the hospital, intravenous sulbactam/ampicillin therapy was initiated. On the third day of admission, bilateral enlarged tonsils were still visible in the physical examination. Upon suspicion of the inadequacy of the initial incision and drainage, drainage was performed under general anaesthesia. An additional $2 \mathrm{~mL}$ of purulent material was drained from each side. An aerobic culture of the aspirated material was positive for Streptococcus pyogenes. Postoperatively, the patient's condition improved dramatically. She was discharged on the fifth day, and treatment was continued with a course of oral amoxicillin and clavulanate. Elective bilateral tonsillectomy was scheduled. Informed verbal consent was obtained from the family before this report was submitted to the journal.

\section{Discussion}

Peritonsillar abscess can occur in all age groups, but it is most commonly observed in adolescents and young adults. However, bilateral peritonsillar abscess rarely occurs during childhood, and only a few cases have been reported. According to a recent case presentation and literature review, there are only 13 cases of bilateral peritonsillar abscess published. ${ }^{2}$ There are two hypotheses regarding the pathogenesis of peritonsillar abscess. The first hypothesis states that it develops as a complication of acute bacterial tonsillitis. The second hypothesis states that peritonsillar abscess is the infection of the salivary gland in the supratonsillar space. ${ }^{3}$ The most common causative agents are group A streptococci and Staphylococcus aureus.

The diagnosis of bilateral peritonsillar abscess is clinically challenging because of the typical examination findings of peritonsillar abscess, such as unilateral peritonsillar bulging and uvular deviation. The bilateral peritonsillar abscess centrally pushes the uvula forward and causes bilateral peritonsillar swelling. ${ }^{4}$ The differential diagnosis of bilateral peritonsillar abscess includes severe bacterial tonsillitis, infectious mononucleosis and carcinomas of the major salivary glands. In our patient, the diagnosis was established with contrast-enhanced computed tomography, revealing bilateral peritonsillar abscess.

The most emergent and important step of treatment is ensuring the safety of the airway. Surgical intervention is controversial. In cases without airway compromise, antibiotics can be administered alone, without the need for surgical intervention. Needle aspiration or incision and drainage are the surgical treatment options. Needle aspiration is easier, cheaper and less painful, while incision and drainage result in a more efficient drainage of the abscess. ${ }^{4}$ Our patient had to undergo incision and drainage due to an inadequate 
response to needle aspiration. The selected antibiotic therapy was intravenous sulbactam/ampicillin for five days during hospitalisation, and oral amoxicillin and clavulanate were continued for five days after discharge.

According to a recent study, the important clinical predictors of good response to non-surgical treatment are the younger age of patients, fewer acute tonsillitis episodes and smaller abscess. An age greater than 7.5 years is a risk factor for poor response to nonsurgical treatment. Paediatricians should consider non-surgical treatment in younger children. ${ }^{5}$ Tonsillectomy is not indicated after the first episode of peritonsillar abscess. However, in recurrent peritonsillar abscess, bilateral tonsillectomy is advised during the acute episode or after the infection subsides. ${ }^{6}$

Our patient is unique due to a history of unilateral peritonsillar abscess, which recurred as a bilateral abscess one year later. In a study by Wang et al. ${ }^{7}$, increased episodes of prior tonsillitis in all ages and treatment by needle aspiration in children have been associated with an increased risk of recurrent peritonsillar abscess. Peritonsillar abscess is a complication of inappropriate treatment of acute tonsillitis, even in the absence of immune compromise. However, the factors underlying the development of bilateral or recurrent peritonsillar abscess are not established. Bilateral peritonsillar abscess is a rare but lifethreatening complication of tonsillitis. Early recognition and prompt treatment of this clinical situation is important.

\section{Ethics}

Informed Consent: Informed verbal consent was obtained from the family before this report was submitted to the journal.
Peer-review: Externally peer-reviewed.

\section{Authorship Contributions}

Concept: D.Ü., L.A.Y., Design: L.A.Y., Ö.T., Data Collection or Processing: D.Ü., Analysis or Interpretation: L.A.Y., D.Ü., Ö.T., Literature Search: D.Ü., L.A.Y., Writing: D.Ü., L.A.Y., Ö.T.

Conflict of Interest: No conflict of interest was declared by the authors.

Financial Disclosure: The authors declared that this study received no financial support.

\section{References}

1. Glomb NWS, Cruz AT. Respiratory Tract Infectious Emergencies. In: Shaw KN, Bachur RG, editors. Fleisher and Ludwig's Textbook of Pediatric Emergency Medicine. 7th ed. Philadelphia: Lippincott Williams \& Wilkins; 2016:849-50.

2. AlAwadh I, Aldrees T, AlQaryan S, Alharethy S, AlShehri H. Bilateral peritonsillar abscess: A case report and pertinent literature review. Int J Surg Case Rep. 2017;36:34-7.

3. Blair $A B$, Booth $R$, Baugh R. A unifying theory of tonsillitis, intratonsillar abscess and peritonsillar abscess. Am J Otolaryngol. 2015;36:517-20

4. Russell MD, Russell MS. Urgent Infections of the Head and Neck. Med Clin North Am. 2018;102:1109-20.

5. Kim DK, Lee JW, Na YS, Kim MJ, Lee JH, et al. Clinical factor for successful nonsurgical treatment of pediatric peritonsillar abscess. Laryngoscope. 2015;125:2608-11.

6. Greig SR. Current perspectives on the role of tonsillectomy. J Paediatr Child Health. 2017;53:1065-70.

7. Wang YP, Wang MC, Lin HC, Chou P. The impact of prior tonsillitis and treatment modality on the recurrence of peritonsillar abscess: a nationwide cohort study. PLoS One. 2014;9:109887. 